\title{
Time Machine: \\ Going Back Thirty Years
}

Fyodor A. Lukyanov

\author{
Fyodor A. Lukyanov \\ Russia in Global Affairs \\ Editor-in-Chief; \\ National Research University-Higher School of Economics, Moscow, Russia \\ Faculty of World Economy and International Affairs \\ Research Professor \\ SPIN RSCI: 4139-3941 \\ ORCID: 0000-0003-1364-4094 \\ ResearcherID: N-3527-2016 \\ Scopus AuthorID: 24481505000 \\ E-mail: editor@globalaffairs.ru \\ Tel.: (+7) 4959807353 \\ Address: Office 112, 29 Malaya Ordynka Str., Moscow 115184, Russia \\ DOI: $10.31278 / 1810-6374-2021-19-4-5-8$
}

The fall of 2021, just several months before another anniversary of the Soviet Union's disappearance, was filled with growing concern about stability in Eastern Europe. Current developments around relations between Russia and Ukraine, or rather between Russia and the United States in connection with Ukraine, may become a serious milestone in European history after the end of the Cold War. At stake is the basic principle on which politics in Europe has been built since the unification of Germany. It makes sense to take this event as a starting point, because united Germany's decision to join NATO marked the beginning of practical steps to dismantle the European security system.

The postulate that every country has a right to choose membership in military-political alliances (formally, to choose ways to ensure its own security, but actually it 
means choosing allies), enshrined in the Charter of Paris for a New Europe, has since been fundamental. By agreeing to united Germany's membership in NATO, the Soviet Union basically predetermined the future of European security. And no matter how hard Russia objected later, one argument said it all: you yourself had accepted it!

Yet NATO got trapped too. Its automatic and presumably smooth expansion was a political and ideological endeavor, where the military aspect played a secondary role-both in terms of real contribution of the new member states to the Alliance's combat readiness and particularly in terms of its readiness to apply Article 5 of the Collective Defense Treaty to all newcomers. In other words, this was formally implied, but hardly anyone in Washington or Western European capitals seriously intended to start a war with Russia to defend Latvia or Slovakia. This was simply not considered a likely scenario. Firstly, there were vague ideas about Russia's accession to some general security configuration. Secondly, at that time the Russian Federation was so dependent on external partners that they were confident that should a threat arise, it could be dealt with in non-military ways.

Russia was angry. But all its claims implied the negation of the main principle: all decisions are made by NATO. And questioning the latter was unacceptable. NATO may or may not consider someone else's interests, but it never considers them as significant as its own. Also, the central mantra of the entire period from the 1990s to the 2010s was that none of the external players could have a veto over how the Alliance would build relations with the countries that wanted to join it.

But there were limitations, of course. The battle over the wording at the NATO Bucharest summit in 2008, when Germany and France fought off U.S. persistent attempts to approve the Membership Action Plan for Georgia and Ukraine, was caused precisely by the fear of Moscow's sharp response. Yet the compromise reached at the summit actually made things worse. No Membership Action Plan was adopted, but the final document said that the two countries would one day be admitted into the Alliance, without any reservations.

At the diplomatic level, the Kremlin was assured that this was just a declaration, that no one would ever admit these countries, that it was mere politesse and everyone understands it. But this doublethink, recognized almost officially, turned military-political and diplomatic relations into a quagmire 
and destroyed the foundations of trust. This was further aggravated by the fact that in addition to NATO there also was the European Unionformally not related to NATO but making up a single Euro-Atlantic framework with almost identical membership. The 2014 confrontation after the Euromaidan protests erased political boundaries between different European organizations, at least for Moscow.

Thirty years after the beginning of the new era, Moscow seems to have come to the conclusion that maintaining the previous system of omissions and signals becomes unproductive and only deepens the crisis. In fact, the very principle that "the choice of alliances by countries does not concern anyone" needs to be scrapped. This principle is nonsense for the classical geopolitics of the balance of power, but everyone considered it an axiom in recent decades. Today this approach has exhausted itself.

Political development has reached a point where the longstanding controversy over NATO enlargement must somehow be resolved. This can be done either by reiterating the Alliance's rocksolid right to expand, accomplished and potential, or, on the contrary, by acknowledging that the logic "everyone has the right to join the Alliance", which underlay
NATO's expansion after 1991, no longer works. Both options carry numerous risks.

Decorative institutions imitating interaction between Russia and NATO have crumbled. Armed confrontation has resumed, and the North Atlantic Alliance must deliver on its promises. The aggravation in Eastern Europe is a signal that the basic principle of security laid down thirty years ago no longer works. NATO's expansion has shaped the military-political landscape in which we now live. Maintaining it further is fraught with new escalation, while its rejection will require a radical revision of the entire system of views, a readjustment and approval of red lines-for example, by refilling the notion of 'Finlandization' with the positive meaning which it had during the Cold War and which turned into almost a swear word after it. But everything changes.

Thirty years on, the question of Europe's regional setup is back on the agenda, but in a different way. Europe itself has turned into a strategic periphery that does not have common political will and is increasingly focused on itself. Russia is historically and culturally connected with Europe, and this connection cannot be broken. But at the same time, Russia's role in the international arena depends on 
relations with Europe only slightly, Europe, but globally. Without this, because the main global events will its Western partners will never give take place south and east of the up the "sanctity" of the rules adopted Russian borders. The paradox is that in 1990-1991. Having achieved the the topic of the outcome of the Cold goals set at the turn of the century, War and the collapse of the USSR Russia still has not resolved the issue will continue to distract Russia's of its status in the new world order, attention from the more important and this will have to be done in the issues until it closes this chapter. But coming years. Such are the strange in order to achieve new agreements results of the thirty years that have on European security, Russia will passed since the collapse of the have to use its capabilities not in Soviet Union. 